Info Artikel:

\title{
MODEL KUANTUM DALAM PEMBELAJARAN BAHASA INDONESIA
}

\author{
Vebbi Andra \\ IAIN Syaikh Abdurrahman Siddik Bangka Belitung \\ vebbiandra@yahoo.com
}

\begin{abstract}
This research is an action research that uses descriptive methods. The technique of collecting data uses observational studies, documentation, and interviews. While data analysis is done by analyzing all available data from various sources, reducing data where data reduction is done by making abstractions, compiling data in units, namely data arranged in categorized units, categories done while making coding, carry out checks on the validity of data, interpretation of data, and conclusions. The results of the study show that the implementation of Indonesian language learning with a quantum model can be said to have succeeded. This can be seen from the results of the tests (evaluations) carried out by the teacher towards students, where the stages of learning that are carried out (starting from the pre-cycle to the first and second cycles) always experience a continuous increase in good value.
\end{abstract}

\begin{abstract}
Abstrak
Penelitian ini merupakan penelitian tindakan yang menggunakan metode deskriptif. Teknik pengumpulan data menggunakan studi observasi, dokumentasi, dan wawancara. Sedangkan analisis data dilakukan dengan cara menelaah seluruh data yang tersedia dari berbagai sumber, mereduksi data di mana reduksi data dilakukan dengan jalan membuat abstraksi, menyusun data dalam satuan-satuan yaitu data yang telah tersusun dalam satuan-satuan dikategorisasikan, kategori dilakukan sambil membuat koding, mengadakan pemeriksaan keabsahan data, penafsiran data, dan kesimpulan. Hasil penelitian menunjukkan bahwa pelaksanaan pembelajaran bahasa Indonesia dengan model kuantum dapat dikatakan telah berhasil. Hal ini terlihat dari hasil tes (evaluasi) yang dilakukan oleh guru terhadap siswa,
\end{abstract}


di mana dari tahapan-tahapan pembelajaran yang dilakukan (mulai dari prasiklus sampai dengan siklus I dan II) selalu mengalami peningkatan nilai yang baik secara terus-menerus.

Keywords: Quantum Model, Indonesian Languange, Senior Hight School

\section{PENDAHULUAN}

\section{Latar Belakang Masalah}

Mata pelajaran bahasa Indonesia, merupakan bidang studi yang mengisyaratkan standar kompetensi siswa berupa kualifikasi kemampuan minimal siswa terhadap penguasaan pengetahuan, keterampilan, dan sikap positif terhadap bahasa dan sastra Indonesia. Standar kompetensi ini merupakan dasar bagi peserta didik untuk memahami dan merespon situasi lokal, nasional, regional, dan global. Dengan standar kompetensi mata pelajaran bahasa Indonesia ini diharapkan nantinya siswa dapat mengembangkan potensinya sesuai dengan kemampuan, kebutuhan, dan minatnya, serta dapat menumbuhkan penghargaan terhadap hasil karya kesastraan dan hasil intelektual bangsa sendiri.

Depdiknas menyatakan bahwa hal yang terpenting dalam pembelajaran bahasa Indonesia adalah bertujuan agar peserta didik memiliki kemampuan berupa: 1) berkomunikasi secara efektif dan efisien sesuai dengan etika yang berlaku, baik secara lisan maupun tulis, 2) menghargai dan bangga menggunakan bahasa Indonesia sebagai bahasa persatuan dan bahasa negara, 3) memahami bahasa Indonesia dan menggunakannya dengan tepat dan kreatif untuk berbagai tujuan, 4) menggunakan bahasa Indonesia untuk meningkatkan kemampuan intelektual, serta kematangan emosional dan sosial, 5) menikmati dan memanfaatkan karya sastra untuk memperluas wawasan, memperhalus budi pekerti, serta meningkatkan pengetahuan dan kemampuan berbahasa, dan 6) menghargai dan membanggakan sastra Indonesia sebagai khazanah budaya dan intelektual Indonesia. ${ }^{1}$

Dengan begitu dapatlah dipahami, bahwa ruang lingkup pembelajaran bahasa Indonesia ialah mencakup komponen kemampuan berbahasa dan kemampuan bersastra yang meliputi aspekaspek berupa: 1) menyimak, 2) berbicara, 3) membaca, dan 4) menulis. ${ }^{2}$ Secara umum, pembelajaran bahasa Indonesia haruslah memperhatikan hakikat bahasa dan sastra, sebagai sarana komunikasi dari diri siswa terhadap lingkungannya.

Melihat selama ini proses pembelajaran bahasa Indonesia terhadap siswa, khususnya pada siswa SMA (Sekolah Menengah Atas) berlangsung kurang baik dan menarik. Di mana pembelajaran bahasa Indonesia untuk siswa SMA (Sekolah Menengah Atas) lebih menekankan kepada model tradisional yang cendrung kaku dan monoton, sehingga mengakibatkan tujuan dari pembelajaran bahasa Indonesia cendrung tidak tercapai oleh siswa SMA (Sekolah Menengah Atas).

Hal ini sejalan dengan pendapat Depdiknas bahwa model tradisional cendrung memiliki kekurang, di mana siswa berperan sebagai penerima informasi secara pasif, siswa belajar secara individual, pembelajaran sangat abstrak dan teoretik, perilaku siswa dibangun atas dasar kebiasaan, bahasa diajarkan dengan pendekatan struktural yaitu rumus diterapkan sampai paham kemudian dilatihkan, dan guru adalah penentu jalannya proses pembelajaran, serta pembelajaran tidak memperhatikan pengalaman siswa. ${ }^{3}$

${ }^{1}$ Departemen Pendidikan Nasional, Panduan Pengembangan Silabus Mata Pelajaran Bahasa Indonesia, (Jakarta: Depdiknas, 2006), hlm. 231-232.

${ }^{2}$ Departemen Pendidikan Nasional, Panduan..., hlm. 232.

${ }^{3}$ Departemen Pendidikan Nasional, Pendekatan Kontekstual (Contextual Teaching and Learning), (Jakarta: Depdiknas, 2002), hlm. 7. 
Dengan adanya perubahan kurikulum pendidikan, di mana kurikulum yang diterapkan sekarang adalah K-13 (Kurikulum 2013), maka dengan begitu juga diperlukan suatu perubahan besar dalam proses pembelajaran bahasa Indonesia, khususnya untuk tingkat SMA (Sekolah Menengah Atas). Oleh kerena itu, seiring dengan adanya perubahan kurikulum ini, maka untuk menciptakan keadaan yang lebih kondusif di sekolah diperlukanlah suatu model baru dalam pembelajaran bahasa Indonesia. Di mana model yang sangat tepat dan sesuai untuk diterapkan di tingkat SMA (Sekolah Menengah Atas), yaitu berupa pembelajaran dengan model kuantum.

Model kuantum sebagai suatu model dalam pembelajaran ialah digunakan untuk menciptakan lingkungan belajar yang efektif, sehingga memudahkan jalannya proses belajar. Pembelajaran dengan model kuantum menekankan pada delapan kunci keunggulan, yaitu: 1) integritas (kejujuran), 2) kegagalan awal kesuksesan, 3) bicaralah dengan niat baik, 4) hidup di saat ini, 5) komitmen, 6) tanggung jawab, 7) sikap luwes (fleksibel), dan 8) keseimbangan. ${ }^{4}$

Berdasarkan penjelasan-penjelasan yang ada di atas, maka penulis sangat tertarik untuk mengadakan suatu penelitian yang berhubungan dengan pelaksanaan pembelajaran dengan model kuantum dalam meningkatkan hasil belajar pada mata pelajaran bahasa Indonesia siswa kelas XII IPS 3 SMA (Sekolah Menengah Atas) Negeri 8 Kota Bengkulu tahun pelajaran 2016/2017.

Alasan penulis meneliti mengenai pelaksanaan pembelajaran dengan model kuantum dalam meningkatkan hasil belajar pada mata pelajaran bahasa Indonesia siswa kelas XII IPS 3 SMA (Sekolah Menengah Atas), ialah dikarenakan bahwa penelitian terhadap hal tersebut belum pernah dilakukan. Selain itu juga, penelitian ini sangat penting dikarenakan pembelajaran dengan model kuantum sangatlah besar peranannya dalam memajukan mutu pendidikan di sekolah khususnya, dan di Indonesia pada umumnya.

\section{Perumusan Masalah}

Berdasarkan identifikasi area dan fokus penelitian, serta pembatasan fokus penelitian yang ada, maka perumusan masalah dalam penelitian ini adalah "Bagaimanakah Bentuk-Bentuk Pelaksanaan Pembelajaran dengan Model Kuantum dalam Meningkatkan Hasil Belajar pada Mata Pelajaran Bahasa Indonesia Siswa Kelas XII IPS 3 SMA (Sekolah Menengah Atas) Negeri 8 Kota Bengkulu Tahun Pelajaran 2016/2017?”.

\section{KAJIAN TEORI}

\section{Hakikat Model Kuantum}

Sebagai metode pembelajaran, model kuantum merupakan konsep belajar yang digunakan untuk menciptakan lingkungan belajar yang efektif, sehingga memudahkan jalannya proses belajar-mengajar. Menurut DePorter dkk. model kuantum memodelkan filosofi pengajaran dan strateginya pada kerangka rancangan yang dirumuskan sebagai TANDUR, yang terdiri atas:

a. Tumbuhkan, yang maksudnya tumbuhkan minat dengan memuaskan "Apakah Manfaatnya Bagiku”, dan memanfaatkan kehidupan pelajar.

b. Alami, yang maksudnya ciptakan atau datangkan pengalaman umum yang dapat dimengerti semua pelajar.

c. Namai, yang maksudnya sediakan kata kunci, konsep, model, rumus, strategi; atas sebuah 'masukan'.

\footnotetext{
${ }^{4}$ Bobbi DePorter dkk., Quantum Teaching: Mempraktikkan Quantum Learning di Ruang-
} Ruang Kelas, (Jakarta: Kaifa, 2004), hlm. 4. 
d. Demonstrasikan, yang maksudnya sediakan kesempatan bagi pelajar untuk 'menunjukan bahwa mereka tahu'.

e. Ulangi, yang maksudnya tunjukkan pelajar cara-cara mengulang materi dan menegaskan, 'aku tahu bahwa aku memang tahu ini'.

f. Rayakan, yang maksudnya pengakuan untuk penyelesaian, partisipasi, dan pemerolehan keterampilan dan ilmu pengetahuan. ${ }^{5}$

Sebagai model yang dikembangkan dan bertumpuh pada wawasan yang berasal dari teoriteori pendidikan, pembelajaran model kuantum berorientasi pada prinsip bahwa pemahaman terbentuk melalui hubungan timbal balik antara guru dan siswa. Di mana inti dari pembelajaran model kuantum berpusat pada asas utama kegiatan pendidikan, yaitu "Bawalah Dunia Mereka ke Dunia Kita, dan Antarkan Dunia Kita ke Dunia Mereka”. DePorter dkk. menyatakan bahwa pada prinsipnya model kuantum berorientasi pada suasana pembelajaran yang menggairahkan, di mana hal tersebut tersusun atas enam komponen, yaitu:
a. Kekuatan terpendam niat.
b. Jalinan rasa simpati dan saling pengertian.
c. Keriangan dan ketakjuban.
d. Pengambilan resiko.
e. Rasa saling memiliki.
f. Keteladanan. ${ }^{6}$

DePorter dkk. menyatakan bahwa model kuantum adalah penggubahan belajar yang meriah, dengan segala suasananya yang menyertakan segala kaitan, interaksi, dan perbedaan yang memaksimalkan momen belajar, serta berfokus pada hubungan dinamis dalam lingkungan kelas hingga memunculkan interaksi yang mendirikan landasan dan kerangka untuk belajar. ${ }^{7}$

Berdasarkan pendapat tersebut, dapatlah disimpulkan bahwa model kuantum adalah pembelajaran yang berlangsung dalam suasana yang meriah, dengan tujuan untuk memunculkan lingkungan belajar yang efektif hingga memudahkan terjadinya proses belajar.

\section{Hakikat Mata Pelajaran Bahasa Indonesia}

Mata pelajaran bahasa Indonesia merupakan suatu bentuk bidang studi yang diarahkan untuk meningkatkan kemampuan siswa untuk berkomunikasi dalam bahasa Indonesia dengan baik dan benar, baik secara lisan maupun tulisan, serta menumbuhkembangkan apresiasi terhadap hasil karya bahasa dan kesastraan Indonesia. Menurut Depdiknas standar kompetensi mata pelajaran bahasa Indonesia merupakan kualifikasi kemampuan minimal peserta didik yang menggambarkan penguasaan pengetahuan, keterampilan, dan sikap positif terhadap bahasa dan sastra Indonesia. Standar kompetensi ini merupakan dasar bagi peserta didik untuk memahami dan merespon situasi lokal, nasional, regional, dan global. ${ }^{8}$

Dengan standar kompetensi mata pelajaran bahasa Indonesia ini diharapkan nantinya: a) peserta didik dapat mengembangkan potensinya sesuai dengan kemampuan, kebutuhan, dan minatnya, serta dapat menumbuhkan penghargaan terhadap hasil karya kesastraan dan hasil

\footnotetext{
${ }^{5}$ Bobbi DePorter dkk., Quantum..., hlm. 10.

${ }^{6}$ Bobbi DePorter dkk., Quantum..., hlm. 17.

${ }^{7}$ Bobbi DePorter dkk., Quantum..., hlm. 17.

${ }^{8}$ Departemen Pendidikan Nasional, Panduan..., hlm. 231.
} 
intelektual bangsa sendiri, b) guru dapat memusatkan perhatian kepada pengembangan kompetensi bahasa peserta didik dengan menyediakan berbagai kegiatan berbahasa dan sumber belajar, c) guru lebih mandiri dan leluasa dalam menentukan bahan ajar kebahasaan dan kesastraan sesuai dengan kondisi lingkungan sekolah dan kemampuan peserta didik, d) orang tua dan masyarakat dapat secara aktif terlibat dalam pelaksanaan program kebahasaan dan kesastraan di sekolah, e) sekolah dapat menyusun program pendidikan tentang kebahasaan dan kesastraan sesuai dengan keadaan peserta didik dan sumber belajar yang tersedia, dan f) daerah dapat menentukan bahan dan sumber belajar kebahasaan dan kesastraan sesuai dengan kondisi dan kekhasan daerah dengan tetap memperhatikan kepentingan nasional.

Depdiknas menyatakan bahwa hal yang terpenting dalam pembelajaran bahasa Indonesia adalah bertujuan agar peserta didik memiliki kemampuan sebagai berikut: a) berkomunikasi secara efektif dan efisien sesuai dengan etika yang berlaku, baik secara lisan maupun tulis, b) menghargai dan bangga menggunakan bahasa Indonesia sebagai bahasa persatuan dan bahasa negara, c) memahami bahasa Indonesia dan menggunakannya dengan tepat dan kreatif untuk berbagai tujuan, d) menggunakan bahasa Indonesia untuk meningkatkan kemampuan intelektual, serta kematangan emosional dan sosial, e) menikmati dan memanfaatkan karya sastra untuk memperluas wawasan, memperhalus budi pekerti, serta meningkatkan pengetahuan dan kemampuan berbahasa, dan f) menghargai dan membanggakan sastra Indonesia sebagai khazanah budaya dan intelektual Indonesia. $^{9}$

Dengan begitu dapatlah dipahami, bahwa ruang lingkup pembelajaran bahasa Indonesia ialah mencakup komponen kemampuan berbahasa dan kemampuan bersastra yang meliputi aspekaspek sebagai berikut: a) menyimak, b) berbicara, c) membaca, dan d) menulis. ${ }^{10}$

Berdasarkan uraian di atas, maka dapatlah disimpulkan bahwa pembelajaran bahasa Indonesia adalah merupakan suatu bentuk bidang studi yang diarahkan untuk meningkatkan kemampuan siswa untuk berkomunikasi dalam bahasa Indonesia dengan baik dan benar, baik secara lisan maupun tulisan, yang terdiri dari empat kemampuan penting, yaitu keterampilan menyimak, berbicara, membaca, dan menulis, serta diharapkan siswa dapat menumbuhkembangkan apresiasi terhadap hasil karya bahasa dan kesastraan Indonesia.

\section{Hakikat Siswa SMA (Sekolah Menengah Atas)}

Menurut Depdiknas siswa atau peserta didik adalah manusia dengan segala fitrahnya. Mereka mempunyai perasaan dan pikiran serta keinginan atau aspirasi. Mereka mempunyai kebutuhan dasar yang perlu dipenuhi (pangan, sandang, dan papan), kebutuhan akan rasa aman, kebutuhan untuk mendapatkan pengakuan, dan kebutuhan untuk mengaktualisasikan dirinya (menjadi dirinya sendiri sesuai dengan potensinya). ${ }^{11}$

Dalam tahap perkembangannya, siswa SMA (Sekolah Menengah Atas) berada pada tahap periode perkembangan peralihan, yaitu dari masa remaja menuju ke tahap dewasa. Oleh karena itu, siswa SMA (Sekolah Menengah Atas) sangat perlu mendapatkan ilmu pengetahuan dan juga mengasah kemampuannya baik dari segi kognitif, afektif, maupun psikomotor. Hal ini dilakukan, adalah agar pengalaman dan kemampuan yang dimiliki siswa SMA (Sekolah Menengah Atas) dapat menjadi bertambah dan meningkat dengan pesat.

\footnotetext{
${ }^{9}$ Departemen Pendidikan Nasional, Panduan..., hlm. 231-232.

${ }^{10}$ Departemen Pendidikan Nasional, Panduan..., hlm. 232.

${ }^{11}$ Departemen Pendidikan Nasional, Panduan..., hlm. 3.
} 
Berdasarkan penjelasan di atas, maka dapatlah disimpulkan dan dipahami bahwa siswa (peserta didik) SMA (Sekolah Menengah Atas) adalah manusia dengan segala fitrahnya, yang sedang menempuh pendidikan pada jenjang sekolah menengah atas dengan tujuan untuk mendapatkan ilmu dan pengetahuan yang bermanfaat, baik dari sigi kognitif, psikomotor, maupun afektif.

\section{Acuan Teori Rancangan Siklus Penelitian}

Rancangan siklus penelitian ini adalah didasarkan atas jenis penelitian yang dilakukan, yaitu berupa penelitian tindakan kelas (classroom action research). Menurut Tim Penelitian PGSM penelitian tindakan adalah:

"Suatu bentuk kajian yang bersifat reflektif oleh pelaku tindakan, yang dilakukan untuk meningkatkan kemampuan rasional dari tindakan-tindakan mereka dalam melaksankan tugas, memperdalam pemahaman terhadap tindakan-tindakan yang dilaksanakan itu, serta memperbaiki kondisi di mana praktik-praktik pembelajaran itu dilakukan." ${ }^{\prime 2}$

Berdasarkan karakteristik penelitian yang akan dilakukan dan juga berpatokan atas teori di atas, maka rancangan pelaksanaan siklus penelitian yang akan dilakukan dalam penelitian ini, adalah berlangsung sebanyak dua siklus. Hal ini dilakukan ialah agar memperoleh dan menghasilkan suatu hasil penelitian yang baik.

\section{Pengembangan Konseptual Perencanaan Tindakan}

Konsep pengembangan perencanaan tindakan dalam penelitian ini adalah bertumpuh pada bentuk-bentuk pelaksanaan pembelajaran dengan model kuantum dalam meningkatkan hasil belajar pada mata pelajaran bahasa Indonesia siswa kelas XII IPS 3 SMA (Sekolah Menengah Atas) Negeri 8 Kota Bengkulu tahun pelajaran 2016/2017. Di mana perencanaan pengembangan dalam penelitian tindakan kelas ini, tersusun atas beberapa tahapan, yaitu:

\section{Perencanaan Persiapan Tindakan}

Perencanaan persiapan ini meliputi: a) menetapkan kelas penelitian, yaitu siswa kelas XII IPS 3 SMA Negeri 8 Kota Bengkulu tahun pelajaran 2016/2017, b) menetapkan waktu dilakukannya penelitian, c) menetapkan materi dalam proses pembelajaran, d) menyusun rencana pembelajaran, e) membuat lembar observasi, dan f) menetapkan cara pelaksanaan refleksi yang dilakukan setiap selesai pemberian tindakan pada setiap siklusnya.

\section{Perencanaan Pelaksanaan Tindakan}

Perencanaan pelaksanaan ini meliputi: a) melakukan observasi untuk mengetahui kemampuan dasar siswa, b) memberikan motivasi kepada siswa dengan memberikan bimbingan yang baik, c) melaksanakan kegiatan pembelajaran dengan menggunakan model kuantum, d) pelaksanaan refleksi untuk mengkaji isi pembelajaran yang telah dilaksanakan dan membuat rencana tindakan yang baru yang akan dilaksanakan pada siklus berikutnya. Jumlah siklus pada penelitian ini disesuaikan dengan kemajuan dari keberhasilan tindakan, yang diperkirakan cukup sebanyak dua siklus.

12 Departemen Pendidikan dan Kebudayaan, Penelitian Tindakan Kelas, (Jakarta: Depdikbud, 1999), hlm. 6. 


\section{METODE}

Penelitian ini menggunakan pendekatan tindakan, dengan menggunakan metode deskriptif. Dalam dunia pendidikan pendekatan tindakan ditujukan untuk mengkaji peristiwaperistiwa dalam situasi pendidikan terutama proses sosial, yang berupa interaksi antara siswa dengan siswa, siswa dengan guru, guru dengan guru, dan siswa dengan lingkungan. Menurut Tim Penelitian PGSM penelitian tindakan adalah suatu bentuk kajian yang bersifat reflektif oleh pelaku tindakan, yang dilakukan untuk meningkatkan kemampuan rasional dari tindakan-tindakan mereka dalam melaksankan tugas, memperdalam pemahaman terhadap tindakan-tindakan yang dilaksanakan itu, serta memperbaiki kondisi di mana praktik-praktik pembelajaran itu dilakukan. ${ }^{13}$

Dalam penelitian ini, metode deskriptif tindakan adalah digunakan untuk menggambarkan atau mendeskripsikan suatu gejala yang berupa ucapan atau tulisan, serta perilaku guru dan siswa kelas XII IPS 3 SMA Negeri 8 Kota Bengkulu pada saat berlangsungnya proses belajar-mengajar bahasa Indonesia dengan menggunakan model kuantum.

\section{Rancangan Siklus Penelitian}

Penelitian tindakan kelas ini dirancang untuk dilaksanakan sebanyak dua siklus, setiap siklus akan dianalisis dan direfleksikan guru untuk memperoleh data sampai sejauh mana tingkat keberhasilan siswa dalam proses pembelajaran bahasa Indonesia dengan menggunakan model kuantum. Sebelum tindakan dilakukan, peneliti terlebih dahulu mempersiapkan hal-hal, berupa:

a. Program Satuan Pembelajaran (PSP) atau Rencana Pelaksanaan Pembelajaran (RPP).

b. Skenario Pembelajaran (SP).

c. Lembar observasi atau pengamatan.

d. Teknik penilaian (indikator analisis).

Tindakan dilaksanakan dengan model siklus, yang meliputi siklus pertama dan siklus kedua, yaitu:

\section{Siklus Pertama}

a. Kajian awal (pratindakan).

b. Pencarian fakta (pratindakan).

c. Perumusan masalah umum.

d. Perencanaan tindakan umum.

e. Pelaksanaan tindakan.

f. Observasi dan monitoring.

g. Refleksi.

h. Data tindakan dan hasil.

\section{Siklus Kedua}

Sebelum siklus kedua dilakukan, terlebih dahulu haruslah disiapkan rencana pembelajaran dan media pembelajarannya. Proses pelaksanaan siklus kedua dalam penelitian ini, dapat diuraikan sebagai berikut:

a. Merevisi masalah umum (berdasarkan refleksi dari siklus pertama).

b. Perencanaan tindakan terfokus.

\footnotetext{
${ }^{13}$ Departemen Pendidikan dan Kebudayaan, Penelitian..., hlm. 6.
} 
c. Pelaksanaan tindakan.

d. Observasi dan monitoring.

e. Refleksi.

f. Data tindakan dan hasil.

Peneliti melakukan tindakan satu sesuai dengan skenario pembelajaran. Setelah selesai dilakukannya tindakan satu, siswa diberi tes dan hasilnya dianalisis untuk dijadikan dasar pelaksanaan tindakan dua. Agar pelaksanaan dapat berjalan dengan lancar, maka diperlukan pemantauan (monitor) dari rekan sejawat atau peneliti lain. Pemantauan itu bertujuan ialah untuk mengetahui apakah tindakan itu menunjukan adanya suatu kemajuan dari siswa, terhadap pembelajaran bahasa Indonesia yang disampaikan dengan menggunakan model kuantum. Hasil penelitian ini akan dikaji bersama (antara peneliti dengan rekan sejawat (guru) atau peneliti lain), sebagai bahan tindakan berikutnya bila diperlukan.

\section{Hasil Intervensi Tindakan yang Diharapkan}

Dengan dilakukannya intervensi tindakan dalam penelitian ini, diharapkan nantinya siswa yang selama ini $85 \%$ memperoleh nilai yang rendah (di bawah 6,5), dapat mengalami peningkatan nilai menjadi 6,5 pada saat siklus pertama selesai dilaksanakan. Lalu selanjutnya diharapkan $85 \%$ siswa tersebut, seterusnya dapat mengalami peningkatan nilai pada saat siklus kedua selesai dilakukan.

\section{Analisis Data Interpretasi Hasil Analisis}

Menurut Patton analisis data adalah proses mengatur urutan data, mengorganisasikannya ke dalam pola, kategori, dan satuan variasi dasar. ${ }^{14}$ Pendapat lain menyatakan bahwa analisis data adalah proses mengorganisasikan dan mengurutkan data ke dalam pola, kategori, dan satuan uraian dasar sehingga dapat ditemukan tema dan dapat dirumuskan hipotesis kerja seperti yang disarankan oleh data. ${ }^{15}$

Analisis data dalam penelitian ini didasarkan pada pendapat Moleong, yaitu: ${ }^{16}$

1. Menelaah seluruh data yang tersedia dari berbagai sumber.

2. Mereduksi data, di mana reduksi data dilakukan dengan jalan membuat abstraksi.

3. Menyusun data dalam satuan-satuan, yaitu data yang telah tersusun dalam satuansatuan dikategorisasikan.

4. Kategori dilakukan sambil membuat koding.

5. Mengadakan pemeriksaan keabsahan data.

6. Penafsiran data.

7. Kesimpulan.

PEMBAHASAN

A. Bentuk Pelaksanaan Pembelajaran dengan Model Kuantum

1. Deskripsi Kelas Pembelajaran

\footnotetext{
${ }^{14}$ Lexy J. Moleong, Metode Penelitian Kualitatif, (Bandung: Remaja Rosdakarya, 1991),
} hlm. 103.

${ }^{15}$ Lexy J. Moleong, Metode..., hlm. 103.

${ }^{16}$ Lexy J. Moleong, Metode..., hlm. 190. 
Penelitian ini dilaksanakan di SMA Negeri 8 Kota Bengkulu, khususnya terhadap siswa kelas XII IPS 3 pada tahun pelajaran 2016/2017. Guru yang menjadi subjek penelitian adalah Ibu Nora Vitaria, S.Pd., M.Pd. guru tersebut adalah guru senior (profesional) dan sudah mempunyai pengalaman mengajar di SMA Negeri 8 Kota Bengkulu selama lebih dari 15 tahun. Sedangkan siswa yang menjadi subjek penelitian adalah siswa di kelas XII IPS 3 sebanyak 32 orang siswa, yang terdiri dari 13 orang siswa laki-laki dan 19 orang siswa perempuan. ${ }^{17}$

Pelaksanaan penelitian ini berlangsung dari tanggal 11 Juli 2016 sampai dengan tanggal 31 Agustus 2016. Alasan mengapa lokasi penelitian ini dipilih, hal itu dikarenakan adalah bahwa SMA Negeri 8 Kota Bengkulu dalam proses belajar-mengajarnya sehari-hari sudah menerapkan model kuantum, terutama pada mata pelajaran bahasa Indonesia. Di mana tujuan dari penelitian ini sebenarnya adalah untuk mengetahui bagaimanakah bentuk-bentuk pelaksanaan pembelajaran dengan model kuantum dalam meningkatkan hasil belajar pada mata pelajaran bahasa Indonesia siswa kelas XII IPS 3 SMA Negeri 8 Kota Bengkulu tahun pelajaran 2016/2017.

Pelaksanaan penelitian ini dilakukan sebanyak 2 kali siklus tindakan, di mana pada tahapan prasiklus peneliti tidak sama sekali melakukan proses pengambilan data, namun peneliti terlebih dahulu berupaya untuk seoptimal mungkin dalam hal mengkondisikan kelas agar nantinya tercipta hubungan yang harmonis antara peneliti dengan subjek penelitian. Data penelitian baru diambil pada saat berlangsungnya pelaksanaan siklus I dan siklus II dengan kompetensi dasar pembelajaran ialah menulis puisi. Di mana semua siswa dalam penelitian ini adalah ikut terlibat aktif, artinya semua tingkah laku siswa selama kegiatan belajar mengajar berlangsung, sepenuhnya ialah diamati oleh peneliti agar nantinya diperoleh suatu data yang valid. Begitu pula dalam halnya guru, semua tingkah laku guru saat pembelajaran berlangsung selalu diamati oleh peneliti sehingga nantinya dapat dijadikan suatu data yang konkret dalam penelitian ini.

\section{Kondisi Prasiklus di Kelas Pembelajaran}

Kondisi kelas pembelajaran pada tahapan prasiklus ini ialah boleh dikatakan belum maksimal. Proses pembelajaran bahasa Indonesia dalam hal kompetensi dasar menulis puisi ini, terlihat cenderung kaku dan monoton. Di mana guru lebih menekankan kepada penerapan model pembelajaran yang bersifat tradisional, sehingga mengakibatkan tujuan dari pembelajaran bahasa Indonesia yang diinginkan guru cenderung tidak tercapai oleh siswa.

Melalui pengamatan awal yang penulis lakukan terhadap kondisi prasiklus di kelas pembelajaran, terlihat jelas bahwa model pembelajaran tradisional ini membuat siswa kurang aktif, kreatif, dan inovatif dalam belajar. Di mana pada model pembelajaran tradisional ini tergambar jelas, bahwa siswa cenderung berperan sebagai penerima informasi secara pasif, siswa belajar secara individual, pembelajaran sangat abstrak dan teoretik, perilaku siswa dibangun atas dasar kebiasaan, bahasa diajarkan dengan pendekatan struktural yaitu rumus diterapkan sampai paham kemudian dilatihkan, dan guru adalah penentu jalannya proses pembelajaran, serta pembelajaran tidak memperhatikan pengalaman siswa. ${ }^{18}$

Di mana pada tahapan awal pembelajaran guru membuka pelajaran dengan cara mengucapkan salam kepada siswa. Lalu pembelajaran dilanjutkan dengan tahapan guru memeriksa kehadiran siswa satu persatu dengan cara mengabsennya. Pada tahapan inti pembelajaran, terlihat

\footnotetext{
${ }^{17}$ Dokumentasi SMA Negeri 8 Kota Bengkulu Tahun 2016.

${ }^{18}$ Observasi Awal (Prasiklus) di SMA Negeri 8 Kota Bengkulu Tanggal 18 Juli 2016.
} 
jelas bagaimana cara guru dalam menyampaikan materi pelajaran bahasa Indonesia, khususnya mengenai kompetensi dasar menulis puisi.

Dalam hal ini guru lebih cenderung mengedepankan pembelajaran yang berbasis pada kegiatan pencatatan dan penugasan (latihan). Kegiatan pembelajaran secara keseluruhan berlangsung dengan cara guru mendiktekan materi pelajaran bahasa Indonesia (khususnya mengenai kompetensi dasar menulis puisi), lalu diikuti dengan semua siswa mencatat apa-apa saja materi mengenai menulis puisi yang telah dibacakan oleh guru tersebut dari awal sampai dengan akhir kegiatan. Sedangkan pada tahapan akhir pembelajaran, terlihat jelas bahwa guru memberikan perintah berupa pemberian tugas (penugasan) kepada siswa untuk mengerjakan latihan dalam hal menciptakan dan menuliskan puisi hasil karyanya sendiri.

Proses kegiatan pembelajaran pada tahapan prasiklus ini menyebabkan suasana pembelajaran di dalam kelas, terasa kurang mendukung tujuan dari pembelajaran bahasa Indonesia itu sendiri terhadap siswa (tidak mendukung pencapaian tujuan pembelajaran yang telah ditetapkan oleh guru). Hal ini tentu saja berdampak langsung terhadap hasil pembelajaran siswa itu sendiri (tergambar dari hasil evaluasi siswa yang berbentuk penugasan/latihan), yang mana terlihat jelas bahwa nilai yang diperoleh oleh siswa adalah cenderung tergolong pada tataran tidaklah memuaskan.

Terlebih lagi selama proses belajar mengajar berlangsung banyak hal-hal yang berkaitan dengan tindakan siswa yang sangat mengganggu suasana ketentraman dan kenyamanan di dalam kelas. Di mana siswa lebih sering asik mengobrol sendiri dengan temannya pada saat pembelajaran berlangsung, tidak dengan sungguh-sungguh memperhatikan materi pelajaran yang diberikan oleh guru, tidak memiliki keinginan untuk mencatat materi pelajaran yang diberikan oleh guru dan malah lebih cenderung mencoret-coret kertas bukunya dengan gambar dan pola-pola tertentu, serta berbagai tindakan-tindakan dan bermacam-macam tingkah laku siswa dalam bentuk lainnya yang sama sekali tidak mendukung kekondusifan proses belajar mengajar pada mata pelajaran bahasa Indonesia. $^{19}$

\section{Pelaksanaan Siklus I di Kelas Pembelajaran}

Kondisi kelas pembelajaran pada saat pelaksanaan siklus I ini adalah boleh dikatakan telah maksimal. Pada tahapan awal pembelajaran guru memulainya dengan cara memberikan salam kepada siswa dan melakukan pemeriksaan dan pengecekan terhadap kehadiran siswa pada saat jam mata pelajaran bahasa Indonesia berlangsung (sebagai proses awal yang baik dalam melakukan tahapan interaksi belajar mengajar), lalu pada tahapan selanjutnya proses pembelajaran dilanjutkan dengan cara guru melakukan kegiatan apersepsi terhadap siswa. ${ }^{20}$

Kegiatan apersepsi pada mata pelajaran bahasa Indonesia ini (khususnya mengenai kompetensi dasar menulis puisi), dilakukan dengan cara guru menayangkan gambar (foto) dari penyair-penyair (para pujangga) penulis puisi kenamaan di Indonesia melalui media laptop dan infocus (projectors). Setelah gambar (foto) dari penyair-penyair tersebut ditayangkan oleh guru satu persatu, lalu guru melakukan proses tanya jawab kepada siswa mengenai siapakah orang yang berada di foto (gambar) tersebut. Di mana setelah siswa berhasil menjawab dengan baik dan benar mengenai siapa-siapa orang (pujangga) yang berada di foto (gambar) tersebut, lalu guru secara

${ }^{19}$ Hasil Wawancara dengan Ibu Nora Vitaria, S.Pd., M.Pd. Guru Mata Pelajaran Bahasa Indonesia di SMA Negeri 8 Kota Bengkulu, Tanggal 18 Juli 2016.

${ }^{20}$ Proses Pelaksanaan Siklus I di SMA Negeri 8 Kota Bengkulu Tanggal 21 Juli 2016. 
bersama-sama dengan siswa merayakan keberhasilan tersebut dengan bertepuk tangan secara bersamaan.

Pada tahapan inti pembelajaran, guru secara langsung dengan menggunakan bantuan media laptop dan infocus (projectors), menayangkan tulisan berupa karya-karya puisi terkenal (teks puisi) dari penyair-penyair ternama di Indonesia. Lalu proses pembelajaran dilanjutkan dengan kegiatan diskusi kelas, di mana guru bersama-sama dengan siswa mengamati teks puisi (melalui media infocus/projectors) yang telah ditayangkan tersebut.

Tahapan kegiatan pembelajaran ini adalah bertujuan untuk melatih siswa agar menjadi mandiri, siswa diharapkan dapat menemukan sendiri pengetahuan mengenai konsep-kensep tentang puisi melalui pengalaman sehari-hari yang siswa miliki, baik itu menyangkut tentang diksi (pemilihan kata), semantik (makna), semiotik (tanda), dan ciri-ciri lain yang terdapat di dalam suatu puisi. Tugas guru dalam tahapan kegiatan pembelajaran ini ialah hanya sebagai fasilitator untuk mengarahkan pikiran siswa ke arah tujuan pembelajaran yang benar.

Dengan menemukan sendiri berarti siswa belajar dari pengalaman yang ia temui sendiri di dalam kehidupan dunia nyata. Di mana proses kegiatan menemukan ini sendiri terdapat empat langkah yang harus dilalui siswa, di antaranya: 1) merumuskan masalah, 2) mengamati atau observasi, 3) menganalisis dan menyajikan hasil dalam tulisan, gambar, laporan, tabel, bagan, atau karya lainnya, dan 4) mengkomunikasikan atau menyajikan hasil karya kepada pembaca, teman sekelas, guru atau audiens lainnya. ${ }^{21}$

Setelah siswa memahami secara utuh mengenai konsep-konsep tentang puisi, maka pada tahapan akhir pembelajaran guru secara bersama-sama dengan siswa melakukan proses refleksi. Kegiatan refleksi dalam pembelajaran adalah bertujuan untuk mengulas kembali proses pembelajaran yang berlangsung (dimulai dari tahapan awal sampai dengan tahapan akhir pembelajaran), sehingga nantinya di dalam pembelajaran ini diperoleh suatu kesimpulan yang sama antara guru dan siswa mengenai inti dari materi pembelajaran yang ada.

Pada tahapan akhir pembelajaran ini juga, guru memberikan perintah kepada siswa untuk mengerjakan latihan dalam hal menciptakan dan menuliskan puisi hasil karyanya sendiri. Dalam proses pengerjaan latihan menuliskan puisi ini, guru dengan bantuan media laptop dan infocus (projectors), mencoba memberikan inspirasi terhadap siswa dalam hal menulis puisi dengan cara menayangkan gambar-gambar yang berhubungan dengan keindahan, baik itu berupa pemandangan alam, tumbuhan, hewan, maupun pemandangan semesta lainnya.

Pada proses pengerjaan latihan ini juga, tidak lupa pula guru untuk memutarkan komposisi musik-musik klasik (lagu) sebagai cara dan usaha dari guru untuk memberikan ketenangan dan kerileksan kepada jiwa siswa, sehingga nantinya diharapkan siswa dapat menghasilkan karya puisi milik dirinya sendiri yang memiliki kualitas yang baik, indah, dan bermutu.

\section{Pelaksanaan Siklus II di Kelas Pembelajaran}

Keadaan kelas pembelajaran pada saat pelaksanaan siklus II ini adalah boleh dikatakan sangat maksimal. Proses pembelajaran dari tahapan awal, tahapan inti, dan tahapan akhir kurang lebih adalah sama dengan tahapan pembelajaran pada siklus I, yang membedakannya ialah pada tahapan inti pembelajaran, di mana di dalam siklus II ini guru menambahkan satu kegiatan baru,

${ }^{21}$ Hasil Wawancara dengan Ibu Nora Vitaria, S.Pd., M.Pd. Guru Mata Pelajaran Bahasa Indonesia di SMA Negeri 8 Kota Bengkulu, Tanggal 21 Juli 2016. 
yaitu berupa kegiatan dalam hal nonton bersama antara guru dan siswa berupa tayangan video yang berisikan penampilan sastrawan-sastrawan hebat Indonesia dalam hal membacakan puisi. ${ }^{22}$

\section{B. Bentuk Peningkatan Hasil Belajar dengan Model Kuantum}

\section{Kondisi Hasil Belajar Prasiklus di Kelas Pembelajaran}

Proses evaluasi pada tahapan prasiklus yang dilakukan pada mata pelajaran bahasa Indonesia, khususnya mengenai kompetensi dasar menulis puisi ini diikuti oleh seluruh siswa kelas XII IPS 3 sebanyak 32 orang siswa. Di mana hasil evaluasinya dianalisis dan didapatkanlah data sebagai berikut:

\section{Analisis Evaluasi Prasiklus ${ }^{23}$}

\begin{tabular}{|c|c|c|c|c|}
\hline No. & Nama Siswa & Nilai & Ketercapaian & Ketuntasan \\
\hline 1 & Al Azhar Firdaus & 5,5 & $55 \%$ & Belum Tuntas \\
\hline 2 & Angga Sri Larasati & 5 & $50 \%$ & Belum Tuntas \\
\hline 3 & Anggel Yoga Saputra & 6 & $60 \%$ & Belum Tuntas \\
\hline 4 & Annisa Purwanti & 6 & $60 \%$ & Belum Tuntas \\
\hline 5 & Apridorisman & 5 & $50 \%$ & Belum Tuntas \\
\hline 6 & Cindy Ayu Destari & 5,5 & $55 \%$ & Belum Tuntas \\
\hline 7 & Cintia Permata Sari & 5 & $50 \%$ & Belum Tuntas \\
\hline 8 & Deki Pratama & 6 & $60 \%$ & Belum Tuntas \\
\hline 9 & Diah Fitaloka & 7 & $70 \%$ & Tuntas \\
\hline 10 & Dika Adinda & 6 & $60 \%$ & Belum Tuntas \\
\hline 11 & Diki Saputra & 6 & $60 \%$ & Belum Tuntas \\
\hline 12 & Eca Tulaini & 5 & $50 \%$ & Belum Tuntas \\
\hline 13 & Edo Sastra & 5,5 & $55 \%$ & Belum Tuntas \\
\hline 14 & Erlin Mais & 7,5 & $75 \%$ & Tuntas \\
\hline 15 & Elda Novianti & 6 & $60 \%$ & Belum Tuntas \\
\hline 16 & Henny Puspita Sari & 6,5 & $65 \%$ & Tuntas \\
\hline 17 & Heny Fitria Ningsih & 5 & $50 \%$ & Belum Tuntas \\
\hline 18 & Heryan Agustoni & 5,5 & $55 \%$ & Belum Tuntas \\
\hline 19 & Hidayat & 6 & $60 \%$ & Belum Tuntas \\
\hline 20 & Leza Ardhya Garini & 6 & $60 \%$ & Belum Tuntas \\
\hline 21 & Meliza Afriza & 6 & $60 \%$ & Belum Tuntas \\
\hline 22 & Nurita & 5 & $50 \%$ & Belum Tuntas \\
\hline 23 & Pauline Millenita Anjali & 5,5 & $55 \%$ & Belum Tuntas \\
\hline 24 & Ria Oktari & 5 & $50 \%$ & Belum Tuntas \\
\hline 25 & Rohan Manata Nael Panjai & 6 & $60 \%$ & Belum Tuntas \\
\hline 26 & Septi Sorenvia & 6 & $60 \%$ & Belum Tuntas \\
\hline 27 & Simon Bernaldi Samosir & 5,5 & $55 \%$ & Belum Tuntas \\
\hline 28 & Theo Riska M. & 5,5 & $55 \%$ & Belum Tuntas \\
\hline 29 & Tri Yoga Apriawan & 6,5 & $65 \%$ & Tuntas \\
\hline 30 & Velia Noverma & 6 & $60 \%$ & Belum Tuntas \\
\hline 31 & Yayuk Hastati & 5 & $50 \%$ & Belum Tuntas \\
\hline 32 & Yusron Hanif & 6,5 & $65 \%$ & Tuntas \\
\hline
\end{tabular}

${ }^{22}$ Proses Pelaksanaan Siklus II di SMA Negeri 8 Kota Bengkulu Tanggal 28 Juli 2016.

${ }^{23}$ Hasil Tes Menulis Puisi Karya Sendiri oleh Siswa Kelas XII IPS 3 SMA Negeri 8 Kota Bengkulu pada Tahapan Prasiklus. 
Hasil analisis yang diperoleh:

a. Ketuntasan Belajar Perorangan

1. Jumlah siswa peserta tes

: 32 orang siswa

2. Jumlah siswa yang telah tuntas belajar

: 5 orang siswa

3. Jumlah siswa yang belum tuntas belajar

: 27 orang siswa

b. Ketuntasan Belajar Klasikal

1. Persentase siswa yang telah tuntas belajar : 5 x $100=15,62 \%$

2. Persentase siswa yang belum tuntas belajar : $\underline{27} \times 100=84,37 \%$

Berdasarkan indikator penelitian (bila $85 \%$ orang siswa telah mencapai nilai minimum $6,5)$, maka dari hasil evaluasi yang dilakukan menunjukkan indikator yang tidak memuaskan. Oleh karena itu, diperlukanlah langkah-langkah konkret untuk melakukan suatu perumusan tindakan kelas dengan menerapkan model pembelajaran kuantum.

\section{Peningkatan Hasil Belajar Siklus I di Kelas Pembelajaran}

Tahapan evaluasi pada siklus I ini diikuti oleh seluruh siswa kelas XII IPS 3 sebanyak 32 orang siswa. Di mana hasil dari evaluasi pada mata pelajaran bahasa Indonesia (khususnya mengenai kompetensi dasar menulis puisi) dianalisis dan diperolehlah data sebagai berikut:

\section{Analisis Evaluasi Siklus I ${ }^{24}$}

\begin{tabular}{|c|l|c|c|c|}
\hline No. & \multicolumn{1}{|c|}{ Nama Siswa } & Nilai & Ketercapaian & Ketuntasan \\
\hline 1 & Al Azhar Firdaus & 6,5 & $65 \%$ & Tuntas \\
\hline 2 & Angga Sri Larasati & 5,5 & $55 \%$ & Belum Tuntas \\
\hline 3 & Anggel Yoga Saputra & 6,5 & $65 \%$ & Tuntas \\
\hline 4 & Annisa Purwanti & 6,5 & $65 \%$ & Tuntas \\
\hline 5 & Apridorisman & 5,5 & $55 \%$ & Belum Tuntas \\
\hline 6 & Cindy Ayu Destari & 6,5 & $65 \%$ & Tuntas \\
\hline 7 & Cintia Permata Sari & 5,5 & $55 \%$ & Belum Tuntas \\
\hline 8 & Deki Pratama & 6,5 & $65 \%$ & Tuntas \\
\hline 9 & Diah Fitaloka & 7,5 & $75 \%$ & Tuntas \\
\hline 10 & Dika Adinda & 6,5 & $65 \%$ & Tuntas \\
\hline 11 & Diki Saputra & 6,5 & $65 \%$ & Belum Tuntas \\
\hline 12 & Eca Tulaini & 5,5 & $55 \%$ & Belum Tuntas \\
\hline 13 & Edo Sastra & 6 & $60 \%$ & Tuntas \\
\hline 14 & Erlin Mais & 8 & $80 \%$ & Tuntas \\
\hline 15 & Elda Novianti & 6,5 & $65 \%$ & Tuntas \\
\hline 16 & Henny Puspita Sari & 7 & $70 \%$ & Belum Tuntas \\
\hline 17 & Heny Fitria Ningsih & 6,5 & $55 \%$ & Tuntas \\
\hline 18 & Heryan Agustoni & $65 \%$ & $65 \%$ & Tuntas \\
\hline 19 & Hidayat & & & \\
\hline
\end{tabular}

${ }^{24}$ Hasil Tes Menulis Puisi Karya Sendiri oleh Siswa Kelas XII IPS 3 SMA Negeri 8 Kota Bengkulu pada Tahapan Siklus I. 


\begin{tabular}{|c|l|c|c|c|}
\hline 20 & Leza Ardhya Garini & 6,5 & $65 \%$ & Tuntas \\
\hline 21 & Meliza Afriza & 6,5 & $65 \%$ & Tuntas \\
\hline 22 & Nurita & 5,5 & $55 \%$ & Belum Tuntas \\
\hline 23 & Pauline Millenita Anjali & 6,5 & $65 \%$ & Tuntas \\
\hline 24 & Ria Oktari & 5,5 & $55 \%$ & Belum Tuntas \\
\hline 25 & Rohan Manata Nael Panjai & 6,5 & $65 \%$ & Tuntas \\
\hline 26 & Septi Sorenvia & 6,5 & $65 \%$ & Tuntas \\
\hline 27 & Simon Bernaldi Samosir & 6 & $60 \%$ & Belum Tuntas \\
\hline 28 & Theo Riska M. & 5,5 & $55 \%$ & Belum Tuntas \\
\hline 29 & Tri Yoga Apriawan & 7 & $70 \%$ & Tuntas \\
\hline 30 & Velia Noverma & 6,5 & $65 \%$ & Tuntas \\
\hline 31 & Yayuk Hastati & 6 & $60 \%$ & Belum Tuntas \\
\hline 32 & Yusron Hanif & 7 & $70 \%$ & Tuntas \\
\hline
\end{tabular}

Hasil analisis yang diperoleh:

a. Ketuntasan Belajar Perorangan

1. Jumlah siswa peserta tes : 32 orang siswa

2. Jumlah siswa yang telah tuntas belajar : $: 21$ orang siswa

3. Jumlah siswa yang belum tuntas belajar : 11 orang siswa

b. Ketuntasan Belajar Klasikal

1. Persentase siswa yang telah tuntas belajar : $21 \times 100=65,62 \%$

2. Persentase siswa yang belum tuntas belajar : $11 \times 100=34,37 \%$

Bila dilihat dari indikator penelitian (jika $85 \%$ orang siswa telah mencapai nilai minimum 6,5), maka hasil evaluasi yang dilakukan pada siklus I menunjukkan indikator yang belum memuaskan. Oleh karena itu, diperlukanlah langkah-langkah penting untuk melakukan suatu perumusan tindakan kelas ke tahap berikutnya (pelaksanaan siklus II).

\section{Peningkatan Hasil Belajar Siklus II di Kelas Pembelajaran}

Kegiatan evaluasi pembelajaran pada siklus II ini diikuti oleh seluruh siswa kelas XII IPS 3 sebanyak 32 orang siswa. Di mana hasil dari evaluasi mengenai kompetensi dasar menulis puisi (pada mata pelajaran bahasa Indonesia) dianalisis dan dihasilkanlah data sebagai berikut:

\section{Analisis Evaluasi Siklus II $^{25}$}

\begin{tabular}{|c|l|c|c|c|}
\hline No. & \multicolumn{1}{|c|}{ Nama Siswa } & Nilai & Ketercapaian & Ketuntasan \\
\hline 1 & Al Azhar Firdaus & 7,5 & $75 \%$ & Tuntas \\
\hline 2 & Angga Sri Larasati & 7 & $70 \%$ & Tuntas \\
\hline 3 & Anggel Yoga Saputra & 8 & $80 \%$ & Tuntas \\
\hline 4 & Annisa Purwanti & 8 & $80 \%$ & Tuntas \\
\hline 5 & Apridorisman & 7,5 & $75 \%$ & Tuntas \\
\hline
\end{tabular}

${ }^{25}$ Hasil Tes Menulis Puisi Karya Sendiri oleh Siswa Kelas XII IPS 3 SMA Negeri 8 Kota Bengkulu pada Tahapan Siklus II. 


\begin{tabular}{|c|c|c|c|c|}
\hline 6 & Cindy Ayu Destari & 8 & $80 \%$ & Tuntas \\
\hline 7 & Cintia Permata Sari & 7 & $70 \%$ & Tuntas \\
\hline 8 & Deki Pratama & 7,5 & $75 \%$ & Tuntas \\
\hline 9 & Diah Fitaloka & 8,5 & $85 \%$ & Tuntas \\
\hline 10 & Dika Adinda & 7,5 & $75 \%$ & Tuntas \\
\hline 11 & Diki Saputra & 7 & $70 \%$ & Tuntas \\
\hline 12 & Eca Tulaini & 6 & $60 \%$ & Belum Tuntas \\
\hline 13 & Edo Sastra & 8 & $80 \%$ & Tuntas \\
\hline 14 & Erlin Mais & 8,5 & $85 \%$ & Tuntas \\
\hline 15 & Elda Novianti & 8 & $80 \%$ & Tuntas \\
\hline 16 & Henny Puspita Sari & 8,5 & $85 \%$ & Tuntas \\
\hline 17 & Heny Fitria Ningsih & 6,5 & $65 \%$ & Tuntas \\
\hline 18 & Heryan Agustoni & 8 & $80 \%$ & Tuntas \\
\hline 19 & Hidayat & 7,5 & $75 \%$ & Tuntas \\
\hline 20 & Leza Ardhya Garini & 8,5 & $85 \%$ & Tuntas \\
\hline 21 & Meliza Afriza & 7 & $70 \%$ & Tuntas \\
\hline 22 & Nurita & 6,5 & $65 \%$ & Tuntas \\
\hline 23 & Pauline Millenita Anjali & 8 & $80 \%$ & Tuntas \\
\hline 24 & Ria Oktari & 7,5 & $75 \%$ & Tuntas \\
\hline 25 & Rohan Manata Nael Panjai & 8,5 & $85 \%$ & Tuntas \\
\hline 26 & Septi Sorenvia & 7 & $70 \%$ & Tuntas \\
\hline 27 & Simon Bernaldi Samosir & 6,5 & $65 \%$ & Tuntas \\
\hline 28 & Theo Riska M. & 7 & $70 \%$ & Tuntas \\
\hline 29 & Tri Yoga Apriawan & 8,5 & $85 \%$ & Tuntas \\
\hline 30 & Velia Noverma & 8 & $80 \%$ & Tuntas \\
\hline 31 & Yayuk Hastati & 7,5 & $75 \%$ & Tuntas \\
\hline 32 & Yusron Hanif & 8 & $80 \%$ & Tuntas \\
\hline
\end{tabular}

Hasil analisis yang diperoleh:

a. Ketuntasan Belajar Perorangan

1. Jumlah siswa peserta tes

2. Jumlah siswa yang telah tuntas belajar : 31 orang siswa

3. Jumlah siswa yang belum tuntas belajar : 1 orang siswa

b. Ketuntasan Belajar Klasikal

1. Persentase siswa yang telah tuntas belajar : 31 x $100=96,87 \%$

2. Persentase siswa yang belum tuntas belajar : 1 x $100=3,12 \%$

Jika dilihat dari indikator penelitian (bila $85 \%$ orang siswa telah mencapai nilai minimum 6,5), maka hasil evaluasi yang dilakukan pada siklus II menunjukkan indikator yang sangat memuaskan. Oleh karena itu, dapatlah dipahami dan dinyatakan bahwa pelaksanaan siklus II pada mata pelajaran bahasa Indonesia, khususnya mengenai kompetensi dasar menulis puisi dengan menggunakan model pembelajaran kuantum adalah dinyatakan telah berhasil. 


\section{KESIMPULAN}

Berdasarkan hasil analisis terhadap pelaksanaan pembelajaran dengan model kuantum dalam meningkatkan hasil belajar pada mata pelajaran bahasa Indonesia siswa kelas XII IPS 3 SMA (Sekolah Menengah Atas) Negeri 8 Kota Bengkulu tahun pelajaran 2016/2017, khususnya mengenai kompetensi dasar menulis puisi ialah dapat dikatakan telah berhasil. Hal ini terlihat dari hasil tes (evaluasi) yang dilakukan oleh guru terhadap siswa, di mana dari tahapan-tahapan pembelajaran yang dilakukan (mulai dari prasiklus sampai dengan siklus I dan II) selalu mengalami peningkatan nilai yang baik secara terus-menerus.

Pada tahapan prasiklus terdapat 5 orang siswa yang telah tuntas dalam belajar atau sekitar $15,62 \%$ dan 27 orang siswa yang belum tuntas dalam belajar atau sekitar 84,37\%. Di tahapan siklus I terdapat 21 orang siswa yang telah tuntas dalam belajar atau sekitar $65,62 \%$ dan 11 orang siswa yang belum tuntas dalam belajar atau sekitar $34,37 \%$. Sedangkan pada siklus II terdapat 31 orang siswa yang telah tuntas dalam belajar atau sekitar $96,87 \%$ dan 1 orang siswa yang belum tuntas dalam belajar atau sekitar $3,12 \%$.

Persentase hasil peningkatan pelaksanaan tindakan kelas pada mata pelajaran bahasa Indonesia, khususnya mengenai kompetensi dasar menulis puisi dengan menggunakan model pembelajaran kuantum di kelas XII IPS 3 SMA (Sekolah Menengah Atas) Negeri 8 Kota Bengkulu secara lebih rinci dapat dilihat pada diagram berikut ini:

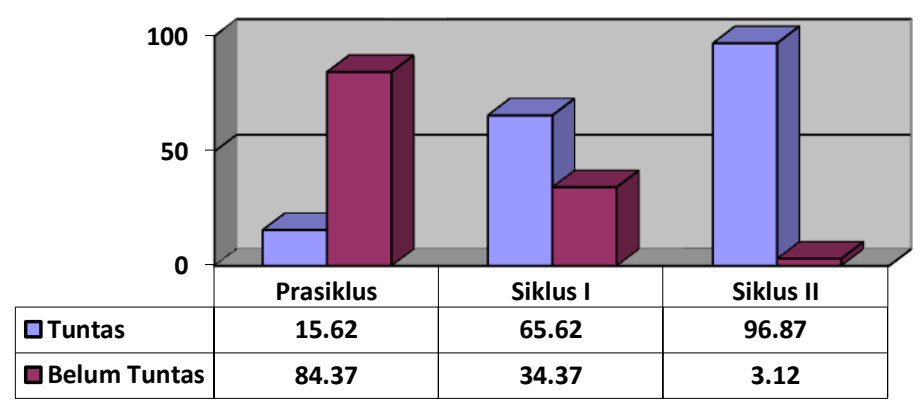




\section{REFERENSI}

Departemen Pendidikan dan Kebudayaan. 1999. Penelitian Tindakan Kelas. Jakarta: Depdikbud.

Departemen Pendidikan Nasional. 2002. Pendekatan Kontekstual (Contextual Teaching and Learning). Jakarta: Depdiknas.

Departemen Pendidikan Nasional. 2006. Panduan Pengembangan Silabus Mata Pelajaran Bahasa Indonesia Sekolah Menengah Pertama. Jakarta: Depdiknas.

DePorter, Bobbi dkk. 2004. Quantum Teaching: Mempraktikkan Quantum Learning di RuangRuang Kelas. Jakarta: Kaifa.

Moleong, Lexy J. 1991. Metode Penelitian Kualitatif. Bandung: Remaja Rosdakarya.

Margono, S. 2005. Metodologi Penelitian Pendidikan. Jakarta: Rineka Cipta.

Narbuko, Cholid dan H. Abu Achmadi. 2005. Metodologi Penelitian. Jakarta: Bumi Aksara.

Nasution, S. 2006. Metode Research. Jakarta: Bumi Aksara.

Sudaryanto. 1988. Metode Linguistik: Bagian Kedua Metode dan Aneka Teknik Pengumpulan Data. Yogyakarta: Gadja Mada University Press.

Sudaryanto. 1990. Aneka Konsep Kedataan Lingual dalam Linguistik. Yogyakarta: Duta Wacana University Press.

Sugiyono. 2005. Memahami Penelitian Kualitatif. Bandung: Alfabet.

Sugiyono. 2008. Metode Penelitian Pendidikan: Pendekatan Kuantitatif, Kualitatif, dan $R$ \& D. Bandung: Alfabeta. 